\title{
CONCEPTUALIZATION OF LEGAL TERMS IN DifFERENT FIELDS OF LAW: THE NEED FOR A TRANSPARENT TERMINOLOGICAL APPROACH
}

\author{
MARTINA BAJCIC \\ martina.bajcic@gmail.com \\ Faculty of Law, University of Rijeka, Croatia
}

\begin{abstract}
Researchers often use subject-specific terminology in order to facilitate communication within a given field of law. Difficulties may arise when they must use scientific information that does not belong to their field. The transfer of information from one subject area to another is restricted by the technical vocabulary used in the particular field. If this is so, what happens when lawyers in one field of law use terms from another? Is the concept in question couched in the same term within another field of law as well? The process of conceptualizing one and the same legal term in different legal fields does not always proceed smoothly. As will be illustrated in this paper, the problem of conceptualizing legal terms in different fields of law calls for a transparent terminological approach. While it is true that legal concepts cannot be fully conveyed by terminology, a transparent terminological approach can contribute to the understanding of these concepts and facilitate their use in legal comparisons, thus making such an approach a conditio sine qua non of legal translation.
\end{abstract}

Key words: subject-specific terminology, conceptualization of legal terms, transparent terminological approach

\section{Introduction}

This chapter examines how notions of EU law are conceptualized at the national level of member states. Above all, it focuses on the process of integrating concepts of EU law into national legal discourse by using national terminology belonging to a different field of law. However, since EU law differs from national law, using terms of national legal discourse to express notions of EU law represents a risky compromise.

In order to analyze the process of conceptualizing one and the same legal term in different legal fields, the following questions will be addressed: Which terms belong to a specific field of law? How should 'interdisciplinary' concepts be classified? How can polysemous terms and synonyms best be treated?

Delimitation of a specific field of law includes establishing conceptual and terminological limits. This is a difficult task because certain concepts can belong to more than one field of law, such as the principle of subsidiarity. Concepts used in more than one field of law are referred to here as interdisciplinary concepts. It is argued that, 
although certain interdisciplinary concepts are expressed by the same term, their conceptualization may differ from one legal field to another. A combined terminological approach should be used to resolve conceptualization and classification difficulties. Such an approach is essential when classifying problematic concepts and translating EU legal texts and finally, providing translation equivalents in the target language. This will be illustrated by examples of concepts of EU law which have been integrated into Croatian national law by using national terminology from a different field of law.

\section{Earlier research}

The problem of classification and conceptualization has received increasing attention not only in the field of terminology and ontology, but in legal translation as well. Within terminology, Felber distinguishes three types of concept classification: Begriffsklassifikation, Themenklassifikation and Gegenstandsklassifikation (2001: 58). Themenklassifikation, or classification according to the topic, serves for documentation purposes and is applied in the library science, whereas in Begriffsklassifikation, or classification according to the concept, concepts correspond ontologically to the object (2001: 58). On the other hand, in Gegenstandsklassifikation, or classification according to the subject, concepts represent encyclopaedic concepts and correspond to the entire object (2001: 58).

Furthermore, Šarčević made it clear that classification plays an important role in law and in legal translation as well:

Classification serves as a catalyst to put the lawyer's mind on the right track, calling up the related concepts and institutions involved in solving the particular problem. Thus terminologists should not deal with isolated concepts but need to compare the conceptual structures of the functional equivalent and its source term by analyzing the conceptual hierarchies to which each belongs (Šarčević 2000: 242-243) ${ }^{1}$.

Especially problematic are legal terms which are used in several legal fields, but convey diverging concepts. Sandrini rightly asserts that the solution to such problematic terms lies in disambiguating them by indicating the legal field in which the concept conveyed by the term in question is used:

Zur Desambiguierung von Rechtstermini genügt es meist, den begrifflich-inhaltlichen Hintergrund der verwendeten Terminologie in jedem Fall durch Angabe des Rechtsbereichs und der Rechtsordnung eindeutig zu kennzeichen (2004: 145).

In the context of EU law, legal concepts have been described as unstable, fuzzy and vague (Kjær 2007: 81) $)^{2}$. As the EU creates its own supranational legal system, its legal

\footnotetext{
${ }^{1}$ Functional equivalent is a terminus technicus in legal translation. As defined by Šarčević, it is "a term designating a concept or institution of the target legal system having the same function as a particular concept of the source legal system" (Šarčević 1989:278-279; 1988: 964, cited in Šarčević 2000: 236).

2 "...EU legal concepts are generally lacking the deep level structure of meaning otherwise characteristic of legal semantics." (Kjær 2007: 81)
} 
terminology differs from the national terminology of the member states. Thus, borrowing national terminology to convey EU legal concepts might lead to ambiguities. This can be avoided by introducing parallel terminology: using one term to denote a legal concept on the national level and another term to denote the concept in question on the EU level. Examples of parallel terminology are found within German legal terminology. In contrast to the term Zivilprozessordnung which is used in German civil law, the term Zivilverfahrensgesetz is used to denote this concept in EU law. The existence of parallel terminology provides clarity in the event of any ambiguities and facilitates legal translation ${ }^{3}$.

In addition, interesting approaches to conceptualization and classification come from various fields of linguistics, such as cognitive linguistics (Langacker 1988; Žic-Fuchs 1991; 2009; Geld 2006) and lexicography (Meyer and Mackintosh 1994: 344; Moerdijk 2003: 291). In cognitive grammar, meaning is equated with conceptualization (see especially Langacker 1988, 1991). Departing from the fundamental notions of cognitive linguistics, Geld analyses aspects of the construal of meaning on the basis of conceptualization (2006). More recently, Christiansen analysed lexical items pertaining to Indigenous land rights in English and Indigenous Australian languages, applying Langacker's cognitive-grammatical model to show different conceptualizations of the notions of possession and property in Anglo-Australian law, as opposed to Indigenous Australian cultures and societies (2010: 285-313).

On the other hand, within ontology, conceptualization is seen as the body of formally represented knowledge which represents "the objects, concepts and other entities that are assumed to exist in some area of interest and the relationships that hold among them (for more detailed research see Genesereth and Nilsson 1987; Madsen and Thomsen 2009 ${ }^{4}$; Gómez Gonález-Jover especially 2006: 219).

However, a strict terminological approach in the sense of Felber's or Wüster's general terminology theory, i.e, the primacy of the concept, associating concepts with a specific knowledge domain, monosemy of terms, or a strict cognitive approach might prove ineffective in solving classification or conceptualization problems that occur in the practice of legal translation. On the other hand, descriptive terminology work conducted by Riggs et al. provides valuable assistance in resolving ambiguities related to interdisciplinary concepts, as is analyzed in the second part of this chapter (Riggs. et al 2000: 184-196; Cábre 2003; Gómez González-Jover 2006, and Faber et al. 2006, 2007). Such a combined terminological approach resolves the problem of conceptualization and classification and is thus instrumental in legal translation. This is illustrated by a short study which analyzes differing conceptualizations of one and the same term in different fields of law. Special attention is paid to achieving clear delimitation of a legal field which constitutes the precondition for classifying interdisciplinary concepts.

\footnotetext{
${ }^{3}$ In this sense the possibility of creating a pan-European legal language, i.e., a neutral metalanguage with common legal concepts at EU level can be further explored. This question sparked a debate among many scholars in the context of the Common Frame of Reference for European Contract Law (see Šarčević 2010: 25).

${ }^{4}$ See Genesereth and Nilsson, 1987 on classification in ontology. Available at:

http://www-ksl.stanford.edu/kst/what-is-an-ontology.html (visited 10 July 2010) and Madsen and Thomsen (2009): Ontologies vs. classification systems. Available at: http://dspace.utlib.ee/dspace/bitstream/1062/984/1/13-4-Final-Ontologies_vs_classification_systems_NODALIDA-2009.pdf
} 


\title{
3. Delimitation of a specific legal field
}

Delimitation of the object of description involves the description of the relevant lexical units and their meaning within a specialised domain. Terminological work has traditionally focused on the organization of concepts and lexical units in a specialised domain, in which each term represents one concept and each concept is denoted by one term. Identifying a specific field of law and which terms belong to that field includes establishing both terminological and conceptual limits. Gómez González-Jover defines technical terms that belong to a specific subject field:

\begin{abstract}
These units are particular to the domain they belong to, and have a highly specific meaning and only one conceptual referent (i.e., units with an 'encapsulated meaning'). In general, technical terms can be found in specialized dictionaries, glossaries, and scientific and technical texts (2006: 221).
\end{abstract}

Such technical terms are said to belong to a specialised language or a sublanguage, the term used by Martin and van der Vliet (2003: 333). A sublanguage covers a special subject field and its most prototypical usage is in communication between experts in the field (Martin and van der Vliet 2003: 333).

However, the boundaries of most subject fields are fuzzy and overlapping subfields may emerge as a consequence of applying different criteria to establish a field. As regards classification, Riggs et al. thus warn terminologists not to regard any field as a rigid intellectual category (2000: 186). This holds true in the field of law and should be taken as the point of departure in legal translation as well.

\section{Practical difficulties of classifying concepts}

The following example from the interdisciplinary field of library science illustrates the problem of classification in different subject fields which apply different classification systems. The need to incorporate new topics and classify new concepts is constantly evolving within library science. In accordance with the UDC, i.e., the universal decimal classification system (corresponding to Felber's Themenklassifikation) used to classify concepts in this field, concepts are classified into different categories and subcategories. One of those categories is the social sciences, whereas law constitutes one of its subcategories. Law is then further subdivided into different subfields. For instance, in the Croatian UDC the concepts zločinačka banda (criminal gang) and zločinačko udruženje (criminal association) are classified under criminal law. However, these concepts are not used in Croatian criminal law. Moreover, they are not cited in the Croatian Criminal Law Act (Official Gazette, No. 110/97) or in other relevant legislation. Instead, Article 89 of the Criminal Law Act defines the concept zločinačka organizacija (criminal organization), which is not included under criminal law in the $\mathrm{UDC}^{5}$.

\footnotetext{
${ }^{5}$ The above problem of classifying legal concepts according to the UDC was the topic of a paper entitled: Terminology Management: UDC vs. Criminal Law Classification, Bajčić M. and
} 
Contrary to the UDC scheme, concepts of criminal law are classified according to authoritative interpretation which usually takes the form of statutory definitions provided by the legislator and is binding erga omnes and ex tunc (Grozdanić and Škorić 2009: 2627). As such, this must be taken into account when classifying concepts of law in UDC tables, despite the fact that other classification rules apply within library science. What more, librarians and terminologists should be constantly on the alert because definitions of legal concepts are subject to change (see Sandrini 1996: 345).

The problem above arose as a result of the literal translation of UDC tables from English into Croatian and the failure to comply with the authoritative interpretation of concepts in criminal law. Unfortunately, this is not an isolated event. Inconsistent terminology has been observed more recently in the usage of the Croatian equivalent in the UDC for the Court of Justice of the EU.

Upon the entry into force of the Treaty of Lisbon, the Court of Justice of the EU is divided into the Court of Justice (formerly the European Court of Justice), the general court (formerly the Court of First Instance) and the Civil Service Tribunal ${ }^{6}$. Furthermore, the Treaty of Lisbon (consisting of the Treaty on the EU and the Treaty on the Functioning of the EU) has not yet been officially translated into Croatian ${ }^{7}$. In the absence of a standardized Croatian translation, Croatian lawyers prefer the term Europski sud for the Court of Justice, whereas librarians use Europski sud pravde, the literal translation in the UDC tables. This can cause confusion among translators and impede the process of information retrieval.

It remains to be seen whether and to what extent such problems of flagrant inconsistency will be resolved. It goes without saying that particular care should be taken when dealing with the classification of concepts belonging to different fields. Interdisciplinary concepts can be especially tricky, as is shown in the following section.

\section{Interdisciplinary concepts}

It has been traditionally presumed that polysemy frequently occurs between fields (Gómez Gonález-Jover 2006: 223). Accordingly, polysemous terms are present in law as well (see Chroma 2004: 34). Nevertheless, in the context of EU law, the term interdisciplinary concepts seems to be more adequate because of the complex relationship between the national laws of the member states and EU law. Hence, the emphasis here is placed on interdisciplinary concepts, i.e. concepts or institutions appearing in more than one legal field. More concretely, such concepts can belong to both the national legal system and to EU law. Although one and the same term is used to denote an interdisciplinary concept, its conceptualization may differ from one legal field to another.

Golenko, D., which was presented at an interdisciplinary conference: Science and Sustainability in Zagreb, Croatia, 8-9 October 2009.

${ }^{6} \mathrm{http}: / /$ eur-lex.europa.eu/LexUriServ/LexUriServ.do?uri=OJ:C:2008:115:0047:0199:EN:PDF (visited 11 August 2010).

7 There was no official Croatian translation of the Treaty of Lisbon in May 2010 when this contribution was presented at the LawTerm 2010 Conference in Łódź, Poland. 
This is illustrated by three basic principles of EU law which lend themselves particularly well to this type of study: subsidiarity, proportionality and primacy (prior to the Treaty of Lisbon: supremacy).

It should be noted that the Treaty of Lisbon which entered into force on 1. 12. 2009, has brought about several terminological and conceptual changes, some of which have already been discussed in this chapter. Therefore, Croatian legal scholars are in the process of introducing new concepts from the Treaty of Lisbon into Croatian law. These concepts are expressed by national legal terminology, which, however, presents some problems. The examples of such concepts mentioned above are by no means exhaustive. They merely serve as an example to examine how terminological problems concerning interdisciplinary concepts can best be resolved.

\subsection{Example 1: Subsidiarity}

According to Article 5 of the Treaty on the Functioning of the European Union, subsidiarity is intended to ensure that decisions are taken as closely as possible to the citizen and that constant checks are made as to whether action at the Union level is justified in light of the possibilities available at national, regional or local level. Specifically, it is the principle whereby the Union does not take action (except in areas under its exclusive jurisdiction) unless it is more effective than action taken at national, regional or local level ${ }^{8}$. In Croatian constitutional law, subsidiarity means that political decisions should be reached at the lowest level possible, bearing in mind the purpose to be achieved (Smerdel 2006: 58). The Croatian term načelo supsidijarnosti is used to denote this concept in both EU law and Croatian constitutional law.

\subsection{Example 2: Proportionality}

The principle of proportionality regulates the exercise of powers by the European Union, seeking to set clear boundaries for the action taken by EU institutions. Under this rule, the institutions' involvement must be limited to what is necessary to achieve the objectives of the Treaties. In other words, the extent of the action must be in keeping with the aim pursued ${ }^{9}$. In Croatian constitutional law the principle of proportionality is interpreted as meaning that any limitation of rights and freedoms must be limited to what is necessary in order to achieve a legal objective (Smerdel 2006: 58). Two Croatian terms are used to denote this concept: načelo proporcionalnosti and načelo razmjernosti. Contrary to the clear differentiation between national and EU terminology illustrated by the example of the German parallel terminology, these two terms are the result of terminological inconsistency; while some legal scholars use one term, others prefer the

\footnotetext{
${ }^{8}$ Available at: http://europa.eu/scadplus/glossary/subsidiarity_en.htm (visited 1 May 2010).

${ }^{9}$ Available at: http://europa.eu/scadplus/glossary/proportionality_en.htm (visited 10 May 2010).
} 
other. Consequently, both terms are used to denote this concept in the context of EU law and Croatian constitutional law. ${ }^{10}$

The necessary terminological precision can be achieved by adding additional descriptors, such as the legal field in which the concept in question is used, e.g. the principle of supsidiarity in EU law, as opposed to the principle of supsidiarity in constitutional law. As Sandrini suggests, indicating the legal field helps to disambiguate a term (2004: 145). In the case of the principle of proportionality, it is recommended to use one Croatian term to denote the concept on the EU level and another for the concept on the national level. This would prevent ambiguities and facilitate legal translation. Otherwise, there is a risk that inconsistent usage of terminology might not only confuse translators of legal texts, but lead to legal uncertainty as well.

\subsection{Example 3: Primacy}

The Declaration concerning primacy $^{11}$ (FR Déclaration relative à la primauté, DE Erklärung zum Vorrang, SL Izjava o primarnosti) was annexed to the Final Act of the Intergovernmental Conference adopted together with the Treaty of Lisbon, signed on 13 December 2007. The Declaration states that, in accordance with the case-law of the Court of Justice of the EU, the Treaties and the law adopted by the Union on the basis of the Treaties have primacy over the law of member states, under the conditions laid down by the said case-law. To examine whether similar concepts exist in Croatian law, the procedure employed in descriptive terminology projects by Riggs et al. is applied. After identifying and delimiting a subject field and compiling an exemplary ${ }^{12}$ corpus of relevant literature, five tasks need to be carried out:

1. identifying the key works in which the subject-field concepts are used;

2. identifying the relevant concepts;

3. defining these concepts;

4. determining which words, phrases or symbols are used as terms to designate them, and

5. $\quad$ selecting contexts to illustrate their usage (Riggs et al. 1997: 185-186).

This procedure can be used to compile a terminological corpus for a specific field and to create conceptual glossaries. In my opinion, a similar procedure can also be helpful when translating interdisciplinary concepts. To illustrate this on the example of primacy, I have compiled a corpus including the Croatian Constitution, relevant legal textbooks,

${ }^{10}$ It is important to differentiate these concepts from the Croatian sudski test proporcionalnosti (judicial control), and the proportionality test in the context of the free movement of goods. Two Croatian terms are used to denote the latter concept test proporcionalnosti and test razmjernosti which leads to further inconsistency and ambiguity.

${ }^{11}$ Available at: http://eurlex.europa.eu/LexUriServ/LexUriServ.do?uri=OJ:C:2008:115:0335:0359:EN:PDF (visited 10 July 2010)

${ }^{12}$ Instead of the term representative literature I prefer exemplary corpus, agreeing with Martin that corpora (for terminological dictionaries) cannot be representative, but at best exemplary (2003: 340). 
scholarly writing, Eurovoc and the Croatian Lexicon of Law. The results of the five-step analysis of the corpus can be summarized as follows:

1. nadređenost (Visković 2006: 180);

2. nadređenost (Ćapeta 2009);

3. nadređenost (Pezo 2010: 768);

4. prvenstvo (in the Croatian translation of Herdeggen's Europarecht, 2003: 221) ${ }^{13}$;

5. prvenstvo (Omejec 2008);

6. primat as the recommended term and prvenstvo (Eurovoc) $)^{14}$;

7. iznad zakona (Smerdel 2006: 185)

8. viši i niži akti (Perić 1994: 106).

The results show that the term nadredenost is used in legal textbooks on constitutional law (first example) as well as in a scholarly paper dealing with the relationship between Constitutional and EU law (second example). In addition, the term nadredenost is an entry term in the Croatian Lexicon of Law (third example). On the other hand, the term prvenstvo is only found in one textbook on European law, which is a translation from German (fourth example), and in a recently published book on EU law (fifth example). It is worth noting that the author of the latter book is the presiding judge of the Constitutional Court of the Republic of Croatia. The term recommended by Eurovoc primat is not a Croatian term and thus not considered an appropriate equivalent for primacy (sixth example).

From the above it can be concluded that the term prvenstvo is used only in the context of EU law, whereas nadredenost is preferred in the context of constitutional law. Examples 7) and 8) list other terms which are not considered relevant for our purpose because they refer to the hierarchy of legal acts.

Having identified the Croatian terms used to denote the concept of primacy, further analysis is needed to determine which of these terms is the most adequate and whether the concept denoted by this term has the same scope of application as the English concept.

\subsection{Conceptual analysis}

Before continuing, a few words should be said about the difference between concept (Begriffsinhalt) and meaning. The former is a cognitive category, whereas the latter is a linguistic one. As Felber points out, certain terms move in a conceptual-semantic field

\footnotetext{
${ }^{13}$ Herdegen's Europarecht was translated from German into Croatian by two professors of law: Prof. Dr. Edita Culinović Herc and Prof. Dr. Nada Bodiroga Vukobrat and published by the Rijeka Faculty of Law in Rijeka 2003. English translations are my own, unless otherwise indicated.

${ }^{14}$ Available at: http://eurovoc.europa.eu/drupal?q=de/search\&text=prvenstvo\%20prava\&cl=hr\&page=1 (visited 10 July 2010)

${ }^{15}$ Constitution of the Republic of Croatia, Art. 134: International agreements concluded and ratified in accordance with the Constitution and made public shall be part of the Republic's internal legal order and shall in terms of legal effect be above law. (Official English translation of the Constitution of the Republic of Croatia, emphasis added.)
} 
(Felber 2001: 58-59) ${ }^{16}$. Similarly, the word field (Wortfeld) reflects the conceptual field (Begriffsfeld) (Trier 1931:1-2). In cognitive linguistics the intertwined relationship of lexical and conceptual knowledge is emphasized by the term lexical concept (Komlev 1976; Žic-Fuchs 1991, 2009). For the purposes of this chapter, it is important to regard a concept as part of a structured concept field in accordance with Felber's view that a concept is a set of common characteristics which can be observed by human beings in a certain number of objects (1982: 123).

The building blocks of conceptual analysis are concepts and characteristics. Characteristics can be classified according to the type of relation existing between the characteristic and the concept it describes, such as attributes (e.g. height, weight) and relations (part, function) (see Felber 2000 for more details) ${ }^{17}$. Similarly, Meyer et al. consider systematic concept analysis to consist of encoding knowledge within a knowledge base (Meyer et al. 1997: 99).

In order to analyze the concept of primacy it is necessary to determine its intension and extension. Intension is the sum of all the characteristics of a concept. It is the internal content of a notion or the sum of the attributes contained in it, which can be identical or variant, just as distribution (Chroma 2004: 31). While the intension of a term includes the set of essential properties which determines the applicability of the term, extension comprises the collection of objects to which a concept refers (Lyons 1977: 158-159, cited in Šarčević 2000: 239). Šarčević considers the scope of application of a concept, i.e., whether the concept can be applied in a concrete fact situation, to be vital for determining the extension of a concept (2000: 244) ${ }^{18}$. Both intension and extension can be narrow or broad and are instrumental for determining whether or not two terms are synonyms. For instance, the concept of claim is expressed by two different Croatian terms which are considered to be synonyms. Tražbina is the term used in the Croatian Obligations Act, whereas the term potraživanje ${ }^{19}$ is used in the Croatian Insolvency Act.

The existence of synonymy in legal language is attributed to non-standardized and inconsistent terminology (Gruntar Jermol 2009: 225). In the field of legal translation synonymy is undesirable as it confuses both experts and translators:

Von Synonymie spricht man auch in dem Fall, wenn innerhalb eines Faches für ein und denselben Begriff mehrere verschiedene Benennungen verwendet werden. Derartige Synonyme sind ein Zeichen einer nicht ausreichend vereinheitlichen Terminologie und sind als solche unerwünscht, da sie nicht nur bei Experten, sondern vor allem bei Überestzern Verwirrung verursachen. (Gruntar Jermol 2009: 225)

16 "Der Begriff ist eine erkenntnistheoretische Kategorie, die Bedeutung eine linguistische. Untersuchungen in einigen Fachgebieten haben gezeigt, dass sich bestimmte Benennungen in einem begrifflich-semantischen Feld bewegen." (Felber 2001: 58-59).

17 Felber names five possible relations between the scope of two or more concepts: "Umfangsgleichheit, Unterordnung, Überordnung, Umfangsüberschneidung, und Ausschließung“" (2000: 62).

${ }^{18}$ Based on intersection and inclusion Šarčević proposes three categories of equivalence for translators in field of law: near equivalence, partial equivalence and non-equivalence (2000: 237-240).

${ }^{19}$ Croatian Obligations Act, Offical Gazette No. 35/2005 , Croatian Insolvency Act, Official Gazette, No. 44/96. 
While legal experts in the field of civil law maintain that the terms tražbina and potraživanje are synonyms and denote the same meaning, the intension of the terms is not absolutely equivalent. Potraživanje has a broader extension and is used more frequently. As for the Croatian terms used to express the concept of primacy, the above analysis shows that the term nadređenost does not have the same extension as prvenstvo, and that these terms are used in different contexts.

One of the main problems for translators working in the field of EU law is to find adequate equivalents for interdisciplinary concepts existing in both the national law and EU law, and whether or not one and the same term may be used to denote such concepts. Furthermore, translators of EU legislation should bear in mind that the meaning of a concept is sometimes determined by the Court, and therefore, they should consult the relevant case-law. Moreover, they need to take account of the fact that the meaning of legal concepts is not fixed, but "in a constant state of flux, being redefined by lawmakers, judges or scholars (Sandrini 1996: 345, cited in Kjær 2007: 81).”

The Court of Justice plays a vital role in the interpretation of concepts of EU law. As a rule, the Court's approach is a teleological one in the sense that it considers the purpose of a given legal rule or a provision, i.e. the will of the legislator, rather than relying on literal interpretation. In other words, the Court finds the meaning by taking into account the purpose of the provision in question. In doing so, it enjoys a great margin of discretion and can define the concept in question extensively ${ }^{20}$.

In light of these considerations it is possible to distinguish linguistic, teleological and legal conceptualizations of the terms nadredenost and prvenstvo on the basis of the above mentioned five-step analysis of the exemplary corpus:

a) The term nadređenost denotes the linguistic conceptualization of quality or condition of being supreme ${ }^{21}$. Hence, to say that EU law is nadredeno (that it has supremacy) over national law, this would mean that national law is subsidiary or subordinate.

b) However, the concept of primacy of EU law as interpreted by the Court of Justice means that national law which is contrary to EU law shall not be applied. It does not imply that national law is subsidiary. This corresponds to the teleological interpretation of the concept of primacy.

c) Thus, a Croatian professor of law ${ }^{22}$ argues that this concept does not involve substantial nadredenost in the sense of higher legal authority or in the context of Constitutional law. In his opinion, the term law in the Declaration concerning primacy is ambiguous as to whether it denotes law or legal acts. Based on other language versions: Recht, droit, the underlying concept is assumed to be law, which could be taken as an argument in favorem of the term nadređenost (a term used in the context of law en generale).

${ }^{20}$ See Lawrie-Blum 66/85, Levin 53/81, Kempf 139/85, Steymann 196/87. A worker can be a student as well as someone who works part-time (Herdeggen 2003: 209).

${ }^{21}$ Entry from the online Croatian dictionary for the term nadređenost: 1. osobina onoga koji je nadređen, svojstvo onog što je nadređeno 2. lingv. odnos dvaju pojmova u kojemu je sadržaj jednoga pojma uključen u sadržaj drugoga, a opseg toga drugoga pojma u sadržaj prvoga, vidi podređen. Available at: www.hjp.hr (visited 10 May 2010)

22 Professor Siniša Rodin elaborated this view at a lecture held at the Faculty of Law of the University of Rijeka at the Postgradute programme in European Integration Law in April 2010. 
d) Finally, the term prvenstvo, which is not used in Croatian legal language, ${ }^{23}$ denotes the state of being first in rank ${ }^{24}$. Although this term is not listed in the Croatian Lexicon of Law it is more neutral than nadredenost and corresponds to the French, German and Slovene equivalents listed at the beginning of the previous section. ${ }^{25}$

In conclusion, it can be said that the analysis of the term nadređenost indicates that legal scholars and researchers in the field of constitutional law conceptualize this term differently than those in the field of EU law. On the basis of the above conceptualizations and especially considering b) and d), the term prvenstvo would be in my opinion a more adequate equivalent than nadređenost for primacy. Unlike the former term which is used in constitutional law, prvenstvo is more neutral and does not refer to a specific field of law. Furthermore, it corresponds to the equivalents for primacy in other EU official languages. Finally, it denotes the concept of primacy in the meaning attached to it by the case-law of the Court of Justice.

Considering that the consolidated versions of the Treaty on European Union and the Treaty on the Functioning of the European Union have not yet been officially translated into Croatian, it remains to be seen which term will be adopted as the official equivalent. At present, Croatian legal scholars are starting to discuss new concepts from the Treaty of Lisbon. In the absence of a standardized Croatian terminology for EU concepts, there is a danger of inconsistency, since legal scholars are using different terms to denote the same concept.

\section{Summary of Findings}

As has been shown, the transfer of concepts from one subject field into another requires a transparent terminological approach. Such an approach includes the following steps: 1) delimitation of a specific legal field by establishing relevant terminological data bases; 2) identifying which terms belong to the particular field, and 3) conducting conceptual analysis.

Caution is necessary when classifying interdisciplinary concepts and 'synonyms', e.g. the principle of proportionality which can belong to Croatian constitutional law and to EU law. Hence, it is important to bear in mind that, although certain interdisciplinary concepts, i.e. concepts used in more than one field of law may be couched in the same term, their 'meaning' may differ from one legal field to another.

In other words, when professors of European law use the term nadređenost, they might not be thinking of the same concept as researchers or lawyers using this term in the field

${ }^{23}$ An exception is found in the context of shareholder's rights to purchase shares under the Croatian legislation (pre-emption right), which is in Croatian law known as pravo prvokupa. However, the Croatian Financial Glossary refers to the latter as to pravo prvenstva. Available at: http://wmd.hr/rjecnik-pojmovi-p/web/pravo-prvenstva-dionicara/ (visited 10 August 2010).

${ }^{24}$ Entry from the online Croatian dictionary: 1. prvo mjesto kao prednost, najviša počast; starješinstvo, prvijenstvo 2. prednost [imati prvenstvo; cesta s pravom prvenstva] Available at: www.hjp.hr (visited 10 May 2010)

${ }^{25}$ It should be noted that a research conducted based on a Croatian corpus wikicroatia (source) resulted in only 4 entries for the term nadređenost, whereas it listed 42 pages for the term prvenstvo. However, these did not include legal meanings of these concepts. 
of constitutional law. From the above study it follows that nadredenost and prvenstvo are conceptualized differently by legal scholars working in different fields of law. Thus, it is essential to follow Felber's advice: "Die Festlegung der Begriffe ist unbedingt nötig für einen Wissenstransfer." (Felber 2001: 60). This can be achieved by means of a transparent terminological approach which resolves difficulties concerning the classification and conceptualization of interdisciplinary concepts, thus proving indispensable in legal translation.

\section{References}

Cabré, M. T. 2003. "Theories of terminology. Their description, prescription and explanation." In Terminology 9(2), Amsterdam: John Benjamins, 163-200.

Ćapeta, Tamara. 2009. "Nacionalni ustav i nadređenost prava EU u eri pravnog pluralizma." Collected papers of Zagreb Law School, year: 59, no. 1: 63-96.

Christiansen, Thomas. 2010. "The Concept of Property and of Land Rights in the Legal Discourse of Australia Relating to Indigenous Groups." In Legal Discourse across Languages and Cultures, edited by Maurizio Gotti \& Christopher Williams, 285-313. Bern: Peter Lang.

Chroma, Marta. 2004. Legal Translation and the Dictionary. Tübingen: Max Niemeyer Verlag.

Felber, Helmut. 2001. Allgemeine Terminologielehre, Wissenslehre und Wissenstechnik. Theoretische Grundlagen und philosophischen Betrachtungen. Wien: Termnet.

Geld, Renata. 2006. "Conceptualization and aspects of construal: fundamental cognitive linguistic notions" in Contemporary Linguistics (Suvremena lingvistika), issue: 62: 183-212.

Gómez Gonález-Jover, Adelina. 2006. "Meaning and anisomoprhism in modern lexicography." Terminology 12:2, 215-234. Amsterdam: John Benjamins: 215-234.

Grozdanić, Velinka and Marissabell Škorić. 2009. Uvod u kazneno pravo. Opći dio, Zagreb: Organizator.

Herdeggen, Matthias. 2003. Europsko pravo. Rijeka: Pravni fakultet Sveučilišta u Rijeci.

Kjær, Anne Lisse. 2007. "Legal Translation in the European Union: A Research Field in Need of a New Approach.” In Language and the Law: International Outlooks edited by Krzysztof Kredens and Stanisław Goźdź Roszkowski, 69-97. Frankfurt am Main: Peter Lang.

Komlev, N. G. 1976. Components of the Content Structure of the Word. The Hague Paris: Mouton.

Langacker, Roland. 1991. Foundations of Cognitive Grammar, Descriptive applications, Vol. II, Stanford, California: Stanford University Press.

-. 1988. "An overview of cognitive grammar." In Rudzka-Ostyn (ed.) Topics in Cognitive Linguistics: 3-47. 
Meyer, Ingrid, Karen Eckand Douglas Skuce. 1997. "Systematic Concept Analysis within a Knowledge-Based Approach to Terminology." In Hanbook of Terminology Management. Vol. I. edited by Sue Ellen Wright and Gerhard Budin, 98-119. Amsterdam Philadelphia: John Benjamins Publishing Company.

Meyer, Ingrid and K. Mackintosh. 2003. "Phraseme analysis and concept analysis: Exploring a symbiotic relationship in the specialized lexicon." In Euralex 1994 Proceedings edited by Martin W., Meijs. M. Moerland, E. ten Pas, P. van Sterkenburg and P. Vossen. The Netherlands. 339-348.

Moerdijk, Fans. 2003. "The codification of semantic information.” In: A Practical Guide to Lexicography, edited by Piet van Sterkenburg. Amsterdam/Philadelphia: John Benjamins Publishing Company: 273-297.

Omejec, Jasna. 2008. Vijeće Europe i Europska unija - institucionalni i pravni okvir. Zagreb: Novi informator.

Perić, Berislav. 1994. Država i pravni sustav. Zagreb: Informator.

Pezo, Vladimir. 2009. Pravni leksikon. Zagreb: Leksikografski zavod Miroslav Krleža.

Riggs, Fred W., Matti Mälkiä, and Gerhard Budin. 1997. Descriptive Terminology in Social Sciences. In Handbook of Terminology Management. Vol. I. edited by Sue Ellen Wright and Gerhard Budin, 184-197. Amsterdam Philadelphia: John Benjamins Publishing Company.

Sandrini, Peter. 2004. „Transantionale interlinguale Rechtskommunikation: Translation als Wissenstransfer." In Rechtssprache Europas, edited by Friedrich Müller and Isolde Burr, 139-157. Berlin: Duncker \& Humblot.

Smerdel, Branko. 2006. Ustavno pravo. Zagreb: Pravni fakultet.

Šarčević, Susan. 2002. "Problems of interpretation in an enlarged European Union." In L'interpretation des textes juridiques rédigés dans plus d'une langue edited by Rodolfo Sacco, 239-273. Italia: L'Harmattan.

Trier, Jost. 1931. Der deutsche Wortschatz im Sinnezirk des Verstandes: Die Geschichte eines sprachlichen Feldes, I von den Anfängen bis zum Beginn des $13 \mathrm{Jh}$. Heidelberg: Winter.

Visković, Nikola. 1995. Država i pravo. Zagreb: Birotehnika.

Willy, Martin, Hennie van der Vliet. 2003. „Design and production of terminological dictionaries." In: A Practical Guide to Lexicography, edited by Piet van Sterkenburg. Amsterdam/Philadelphia: John Benjamins Publishing Company: 333-350.

Žic-Fuchs, Milena. 2009. Kognitivna lingvistika i present perfect. Zagreb: Nakladni zavod Globus.

—. 1991. Znanje o jeziku i znanje o svijetu. Zagreb: SOL. 